\title{
Dysregulation of miR-129-5p in Patients with Non- Alcoholic Fatty Liver Disease and Its Regulatory Effect on Insulin Resistance
}

Research

Keywords:

Posted Date: March 30th, 2021

DOI: https://doi.org/10.21203/rs.3.rs-83173/v2

License: (c) (1) This work is licensed under a Creative Commons Attribution 4.0 International License.

Read Full License 


\section{Abstract}

The authors have requested that this preprint be withdrawn due to author disagreement.

\section{Full Text}

The authors have withdrawn this preprint from Research Square. 